\title{
Video games as a supportive tool in the therapeutic process
}

\author{
Marcin Mateusz Granat \\ Uniwersytet Jagielloński \\ marcin.m.granat@gmail.com | ORCID: 0000-0003-0577-434X
}

\begin{abstract}
The objective of this study was to determine the diseases that are on the rise, and then to investigate whether video games can support their treatment. To achieve the goal a search based on scientific literature was conducted. The results led to the conclusion that video games are an effective tool in the rehabilitation of post-stroke patients. Compared to the standard rehabilitation, patients who were playing video games showed improvement of upper limb motor functions, better static balance and lower anxiety of falling. Similarly, statistically significant improvement measured by Quality of Upper Extremity Skills Test was observed during the rehabilitation of a pediatric group suffering from cerebral palsy. Video games successfully supported the therapy of other juvenile patients by enhancing visual acuity in cases of children amblyopia as well as lowering anxiety during the induction of anaesthesia. Moreover, the usefulness of video games was observed in treating mental disorders. It involved patients with the post-traumatic stress disorder, who presented reduced flashback frequency, and patients with depression, who showed a lower rumination score along with increasing subjective cognition. Indicating which diseases have an increasing morbidity rate as well as demonstrating positive therapeutic responses to video games can provide useful information for public health practitioners and improve the treatment of selected diseases.
\end{abstract}

Keywords: video games, rehabilitation, pediatry, psychiatry 



\section{Objective and methods}

The aim of the study was to determine the therapeutic effects of video games on diseases that are on the rise. The therapeutic effect was defined as positive response(s) after any kind of treatment including rehabilitation and disease-related medical procedures. To achieve the goal, two steps were performed in the following sequence:

- Running a search to determine which diseases are on the rise.

- Running a search to determine if the therapy of the detected diseases can be supported by video games.

The searching process started on 4 September 2020 and ended on 12 December 2020. It was based on browsing scientific bibliographic databases such as: MEDLINE, Cochrane Library, Embase, Ovid MEDLINE and IEEE Xplore. The aforementioned databases were chosen as a primary source of information due to their major role in current scientific communication. The publications taken into account involved the time period from 1988 to 2020 . The searching process was supplemented by studying the Polish edition of the Scientific American magazine (all issues from 2020) and the books: Pediatria (Lissauer, Clayden, 2009) and Psychiatria. Podręcznik dla studentów medycyny (Rabe-Jabłońska, 2011), as well as by seeking additional scientific information via the Google search engine. The last method provided around $10 \%$ of the whole information included in this study. Based on the results a list of diseases was prepared and duplicates were removed. During the research only experiments conducted with a control group were taken into consideration.

The study was conducted according to an algorithm presented in Figure 1 on the next page.

The outcome revealed diseases relevant to the study such as: cerebrovascular accident (stroke; Pistoia, Sacco, Tiseo, Degan, Ornello, Carolei, 2016), cerebral palsy (Aisen, Kerkovich, Mast, Mulroy, Wren, Kay, Rethlefsen, 2011), childhood amblyopia (Fu, Hong, Su, Lou, Pan, Liu, 2019), pediatric brain tumor (Patel, Bhatnagar, Wear, Osiro, Gabriel, Kimball, John, Fields, Tubbs, Loukas, 2014), post-traumatic stress disorder (Committee on the Assessment..., p. 36) and depression (Sarris, O’Neil, Coulson, Schweitzer, Berk, 2014). Video games presented their 
therapeutic usefulness for all these diseases. Detailed results are given in the following sections.

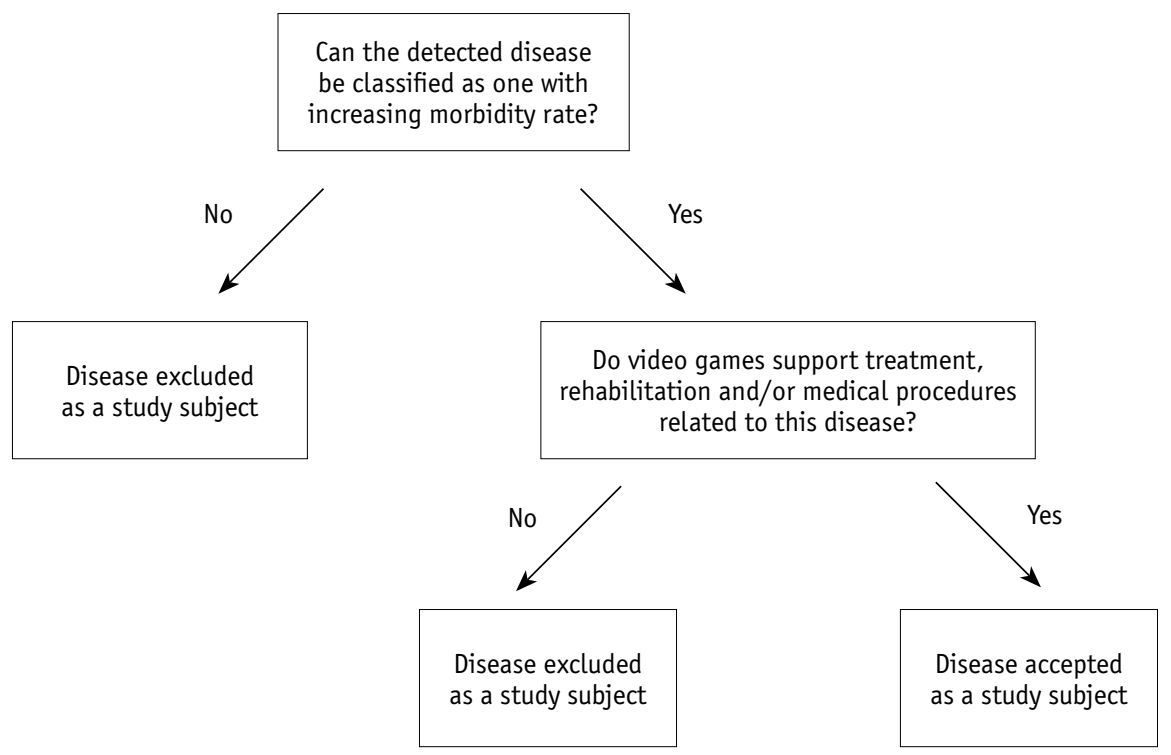

Figure 1. The algorithm applied in selecting the diseases

\section{The choice of a suitable game and its therapeutic effects on post-stroke patients}

15 million people worldwide suffer from cerebrovascular accidents (strokes) every year (World Health Organization, Stroke..., 2020). Globally, stroke is the second cause of death and the third cause of disability (Johnson, Onuma, Owolabi, Sachdev, 2016). There is a prognosis that the European Union will notice a $34 \%$ growth in the number of cerebrovascular accidents in the years 2015-2035 (King's College London for the Stroke Alliance for Europe, 2015).

One of the main complications observed in post-stroke patients is the impairments of the upper limbs motor function (Bonita, Beaglehole, 1988). Rehabilitation plays a key role in recovering this function. Physical exercises are obligatory for inpatients and should be continued after 
leaving the hospital (Goršič, Novak, 2016). Home rehabilitation is strictly connected to the patient's motivation because exercises are executed without professional supervision. Studies proved the ability of video games to increase motivation as well as exercise intensity (Novak, Nagle, Keller, Riener, 2014). There was a relationship between the exercise intensity in performing an upper limb rehabilitation task, the patient's stress level (measured using the galvanic skin response) and the video game difficulty level. In a single player mode, the more difficult levels were played, the higher stress level was noted. Other results were observed during a competitive mode with a human rival, in which the exercise intensity was as high as in the case of the highest difficulty level in the single player mode, but the stress level was lower (Catalán, Blanco, Díez, García, García-Aracil, 2019). Therefore it is safe to claim that the video game rehabilitation effect is affected not only by the game type, but also by the game mode.

The competitive mode (player against player) can be perceived as an easy method to increase exercise motivation without advanced software and hardware modification (Goršič, Novak, 2016). To address this issue, a study was conducted for a group of five patients with neurological problems (4 after a stroke, 1 with a traumatic brain injury) and two patients suffering from orthopedic injuries (shoulder rotator cuff injury). The research was carried out concerning the following game:

- Two-player mode (patient against healthy human rival) with the use of three video games (two with a cooperative mode and one with a competitive mode).

- Single-player mode with the use of one video game.

The participants filled a questionnaire the purpose of which was to subjectively evaluate the games. The results revealed that the majority of patients described the competitive gameplay model as their favourite as well as the most demanding physically. The highest arithmetic mean of hand velocity values was observed for the competitive mode (Table 1), which indicates the participants' noticeable involvement in the gameplay. Due to the fact that the higher video game involvement and intensity were noted, the better rehabilitation effects were, one can assume that the competitive mode is the most promising from the therapeutic point of view. 
Table 1. The hand velocity values and arithmetic means measured for participants in all four game types (source: Goršič, Novak, 2016, p. 4693)

\begin{tabular}{|c|c|c|c|c|}
\hline \multirow{2}{*}{ ID } & \multicolumn{4}{|c|}{ Exercise game } \\
\cline { 2 - 5 } & SP & Competitive & Coop-shared & Coop-split \\
\hline 1 & 0.0804 & $\underline{\mathbf{0 . 1 1 9 4}}$ & 0.1034 & 0.0865 \\
\hline 2 & 0.1105 & $\underline{\mathbf{0 . 1 2 1 8}}$ & 0.109 & 0.0907 \\
\hline 3 & 0.0985 & 0.0747 & $\underline{\mathbf{0 . 1 0 3 9}}$ & 0.0665 \\
\hline 4 & 0.1254 & 0.1295 & 0.1215 & $\underline{\mathbf{0 . 1 4 7 1}}$ \\
\hline 5 & 0.0767 & 0.0900 & 0.0758 & $\underline{\mathbf{0 . 0 9 5 9}}$ \\
\hline 6 & 0.0792 & $\underline{\mathbf{0 . 1 0 1 2}}$ & 0.0857 & 0.0476 \\
\hline 7 & 0.0557 & 0.0616 & $\underline{\mathbf{0 . 0 6 3 2}}$ & 0.0596 \\
\hline Mean & $\mathbf{0 . 0 8 9} \mathbf{~ m} / \mathrm{s}$ & $\mathbf{0 . 1 0 0 ~ \mathbf { m } / \mathbf { s }}$ & $\mathbf{0 . 0 9 5} \mathbf{~ m} / \mathbf{s}$ & $\mathbf{0 . 0 8 5} \mathbf{m} / \mathbf{s}$ \\
\hline
\end{tabular}

In another study, conducted on a larger group (Sin, Lee, 2013), 20 patients suffering from hemiplegia after a stroke received standard rehabilitation and experimental rehabilitation using a video game with the motion sensing input device Xbox Kinect. The control group, also composed of 20 patients, was treated by means of standard rehabilitation. The research was conducted only by using tests for assessing patient mobility: the ROM (range of motion) test, the Fugl-Meyer Assessment test and the Box and Block Test. The analysis of data has shown an increase of patients' mobility in the experimental group. In all tests, except those concerning wrist flexion and extension, the differences between the experimental group and the control group were statistically significant.

A similar project was started in The Hospital de l'Esperança in Barcelona in cooperation with the Pompeu Fabra University and the Vall d'Hebron University Hospital (Barcelona MAR Health Park Consortium, 2015). The project, which was called Rehabilitation Gaming System (RGS), allowed to track the motion of upper extremities and was useful in the 


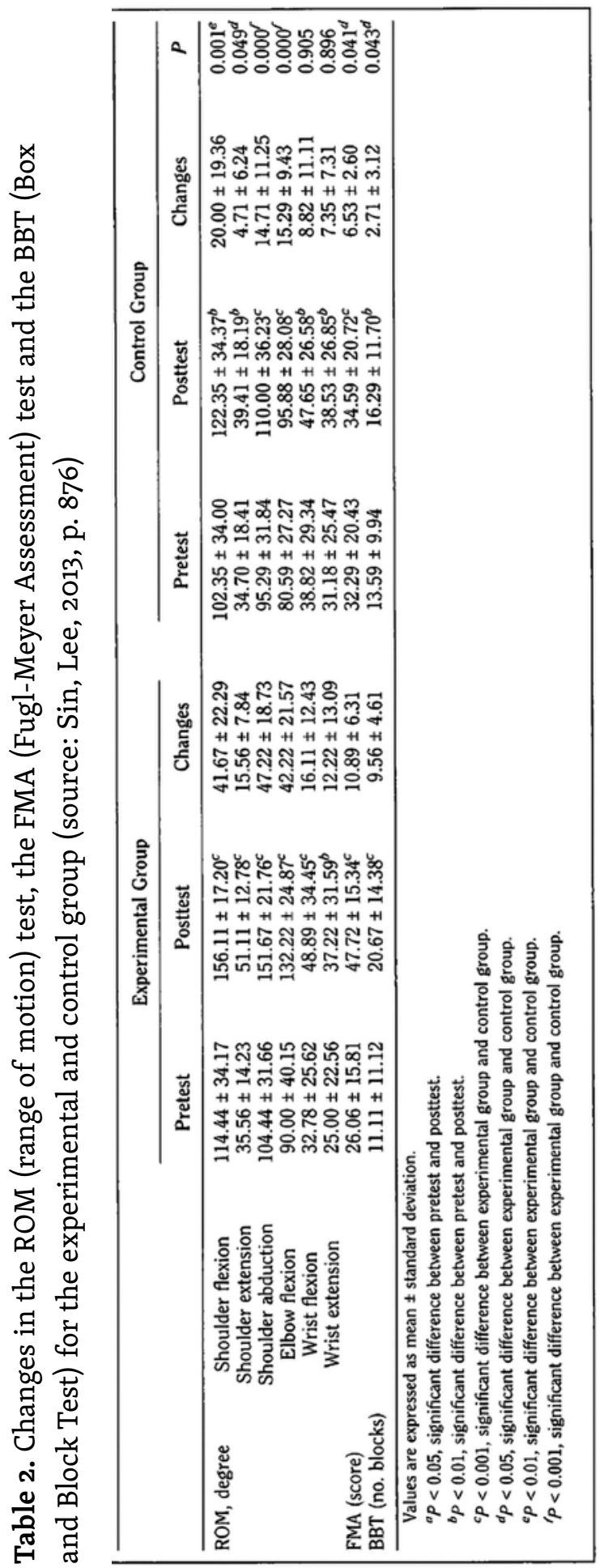


rehabilitation focused on post-stroke patients with upper limb motor dysfunctions. After putting both hands on special controllers, patients observed on the screen a visualization of their limbs. Thereafter, they played a video game with gameplay based on hitting, catching and releasing spheres (Cameirão, Badia, Duarte, Verschure, 2008). Research on RGS was carried out with the use of two control groups. The first control group performed the same motor tasks as the experimental group, but without the use of the Rehabilitation Gaming System. The second control group played different games using the Nintendo Wii, which, like RGS, requires upper extremity motor control.

The results showed ambiguity in mobility, which depended on the test type. In the Fugl-Meyer test the group using RGS presented lower improvement in week 5, compared to the first control group, but then the RGS patient presented constant improvement from week 5 until week 24. During the same time period, the motor functions of the first control group stabilized on the same level, without any improvements. An opposite situation was observed after participants were tested using the Chedoke Arm and Hand Activity Inventory (CAHAI). The first control group achieved better results than the experimental group. This shows the aforementioned ambiguity in the results obtained by multiple rehabilitation tests, which may be solved by further experiments. While analysing the results, it is worth to be mindful of the small number of participants (in the Fugl-Meyer test, as well as in the CAHAI, the results concerned only one person rehabilitated by means of the RGS, and one person from the control group). It is crucial to know that exercises performed with the use of the RGS always have one advantage compared to traditional rehabilitation. It is the RGS' ability to monitor the patients' movements and store that data during the rehabilitation process, which cannot be done with the use of traditional methods (Cameirão, Badia, Duarte, Verschure, 2008).

The rehabilitative role of video games in improving post-stroke patients' motor functions is not limited to increasing the mobility of the upper limbs. Groups which participated in video game rehabilitation also presented a better static balance (Lee, Kim, Lee, 2015) and a lower anxiety of falling (Hung, Chou, Hsieh, Wu, Yu, Chen, 2014). 


\section{Medicinal use of video games in the treatment of pediatric patients}

Video games are an effective tool in treating some pediatric diseases. It has been proven that the act of playing video games by children causes them to feel satisfaction (Jannink, Wilden, Navis, Visser, Gussinklo, Ijzerman, 2008, p. 31; Bonnechère, Jansen, Omelina, Jan, 2016, p. 285). Therefore, one can assume that pediatric patients should easily accept playing video games as a part of their therapy.

Rehabilitative properties of video games were studied in children suffering from cerebral palsy. This disease, through brain damage, impair patient's motor functions (Lissauer, Clayden, 2009, p. 47). An experiment that examined rehabilitation effects with the use of video games resulted in the conclusion that playing them improves fine motor skills and balance (Sandlund, Waterworth, Häger, 2011, p. 19). Researchers conducted a randomized controlled trial on 20 children with cerebral palsy and observed their motivation and enthusiasm to perform exercises. To that aim a video game with Nintendo Wii's wireless motion sensing input controller was used (Sajan, John, Grace, Sabu, Tharion, 2016). During the recruitment to the experiment, which lasted from March 2012 to December 2013, the control group as well as the intervention group were homogenous in the motor function aspects. After the experiment the intervention group showed statistically significant improvement in the total QUEST (Quality of Upper Extremity Skills Test) score, which was absent in the control group $(Z=-1.604, p=0.109$ in the control group, and $\mathrm{Z}=-2.207, \mathrm{p}=0.027$ in the intervention group).

Another field of medicine in which video games have proven their usefulness is pediatric ophthalmology. The nowadays gold-standard treatment for childhood amblyopia is patching the fellow eye. This procedure results in the improvement of visual acuity after 120 hours. In a recent study (Gambacorta, Nahum, Vedamurthy, Bayliss, Jordan, Bavelier, Levi, 2018, pp. 4-8) scientists proposed an alternative method with the use of a video game. Pediatric patients with unilateral amblyopia were divided into two groups and asked to complete 20 hours of game play. The first group $(n=11)$ accomplished the task monocularily with 
the fellow eye patched, and the second group $(n=10)$ played the game dichoptically with reduced contrast to the fellow eye. Both groups showed improvements in visual acuity measured by mean change using Bailey-Lovie logMAR letter charts. The dichoptic group improved by $0.14 \pm 0.02 \log M A R$ units after 20 hours of game play and the monocular group improved by $0.06 \pm 0.03 \log$ MAR units. The results indicate that active treatments using video game are as effective in the case of amblyopia as traditional therapy but the goal is achieved in a shorter period of time.

Because of the fact that cases of pediatric brain tumor are on the rise (Patel, Bhatnagar, Wear, Osiro, Gabriel, Kimball, John, Fields, Tubbs, Loukas, 2014, p. 153), the number of surgical operations are increasing as well (Saint-Martin, Apuzzo, Salman, Farmer, 2019). To perform such operations, a special medical procedure, called induction of anaesthesia, must be executed. The goal of the procedure is to calm the patient down before surgery and it is conducted by administering a tranquilliser, such as midazolam (Manyande, Cyna, Yip, Chooi, Middleton, 2015, p. 2). However, medications can cause side effects, e.g. respiratory depression, therefore scientists sought alternative, non-pharmacological methods. Some of them proposed video games as a tool to help patients relax. To verify this assumption clinical trials on children were conducted. The video game playing group was compared with two control groups. The first of them did not perform any action during the induction of anaesthesia, and the second received midazolam as a sedative.

Table 3. Comparison between the video game group and the control group performing no action (source: Manyande et al., 2015, p. 98)

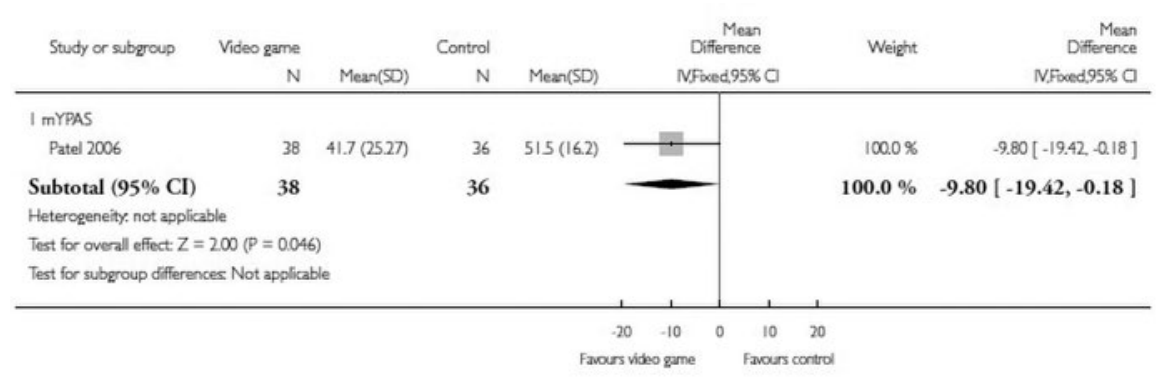


Table 4. Comparison between video game group and group receiving midazolam (source: Manyande et al., 2015, p. 99)

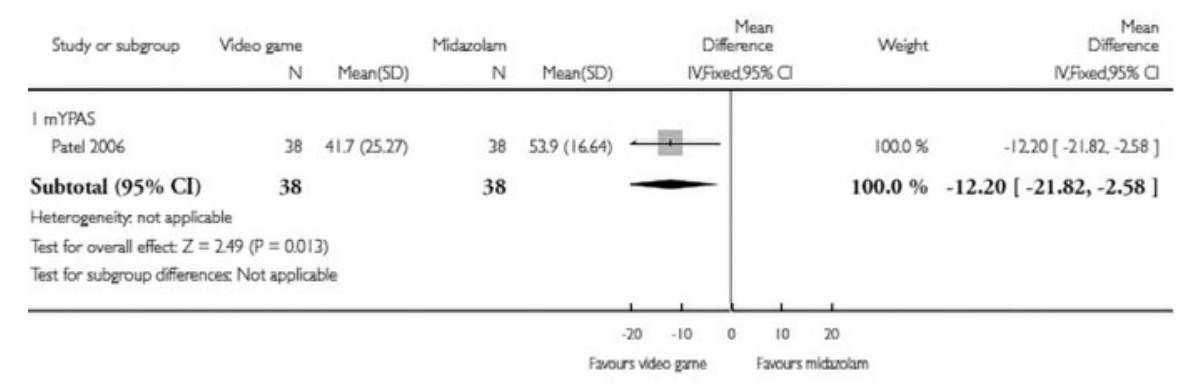

The analysis of differences in mean values (Table 3 and Table 4) leads to the conclusion that the patients who were playing video game during the induction of anaesthesia showed lower anxiety compared to both control groups. Therefore, video games can be taken into consideration as an effective non-pharmacological alternative to standard methods. In both experiments the level of anxiety was measured using the modified Yale Preoperative Anxiety Scale.

\section{The therapeutic potential of video Games in Cases Concerning Mental Disorders}

An example of a mental illness which affects the whole society is the posttraumatic stress disorder (PTSD; Rabe-Jabłońska, 2011, p. 233). It occurs after traumatic experiences and its symptoms include, e.g., disturbing thoughts and nightmares. Based on the facts that memory needs consolidation and that recalling a previously consolidated memories causes them to become fragile and vulnerable to interference again (Walker, Brakefield, Hobson, Stickgold, 2003), a study was conducted to reduce the build-up of flashbacks for trauma (Holmes, James, Kilford, Deeprose, 2010). During the experiment, the participants watched a film of traumatic scenes followed by a 30-minute structured interval. After that a reminder task for a trauma film was assigned to everyone, and then the participants, divided into three groups, performed one of the following activities: playing Tetris Zone, answering the quiz and doing nothing. 
The results showed that in the video game group flashbacks over one week occurred in the smallest number, compared to the other groups. Moreover, there is a possibility that the aforementioned video game properties may be useful during the COVID-19 pandemic. This is because the fear of becoming ill with COVID-19 is related to PTSD symptoms (Mock, 2020).

Table 5. Flashbacks frequency in three groups: video game group, no-task group and quiz group over one week (source: Holmes at al., 2010, p. 4)

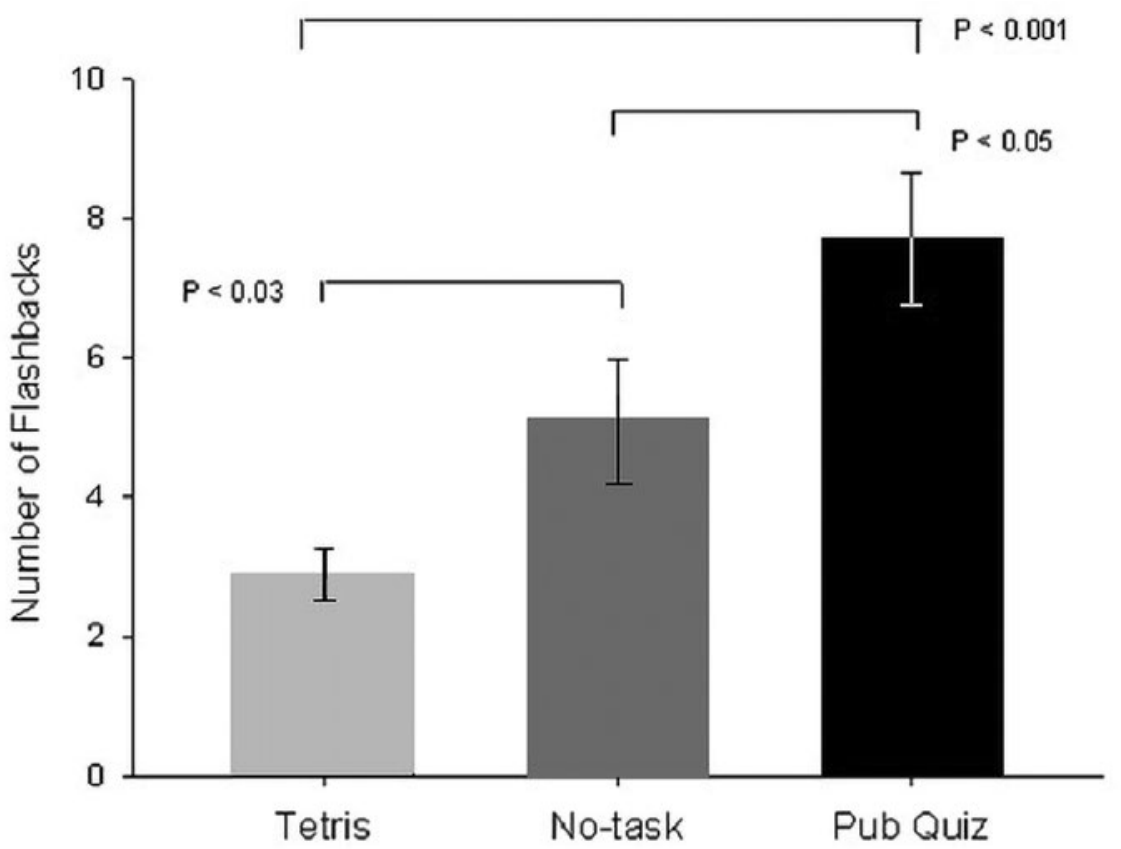

Video games can be helpful for patients suffering from depression a common disease which is affecting over 264 million people globally (World Health Organization, 2020). Cognitive dysfunctions and rumination are examples of many symptoms related to that mental disorder. Based on the fact that playing action video games leads to improvements in cognitive function, a study was conducted to determine the usefulness of action video games for patients with depression (Kühn, Berna, Lüdtke, Gallinat, Moritz, 2018). To that end, two groups were examined: experimental $(n=21)$ and control $(n=29)$. The first group received a six-week 
access to a fast paced action video game Boson $X$. The participants in the second group represented a passive (wait-list) group. The results revealed that the participants who were playing the game, compared to the control group, represented a statistically significant lower rumination score (ANOVA result: $\mathrm{F}=72.65, p=0.017$ ), as well as significantly higher subjective cognition (ANOVA result: $\mathrm{F}=162.31, p=0.043$ ).

\section{Conclusions and difficulties related to applying video games as a therapeutic tool}

The diseases characterised by increasing morbidity rate and positive response to video game therapy are as follows:

- cerebrovascular accident and cerebral palsy (in both cases video games successfully support the rehabilitation process);

- children amblyopia (video game therapy improves patients' visual acuity faster than gold-standard treatment);

- pediatric brain tumor (the disease requires surgery and ipso facto the procedure called induction of anaesthesia, for which video games proved to be more effective than standard methods);

- post-traumatic stress disorder (the patients who were playing a video game reported reduced flashback frequency in comparison to the non-playing group);

- depression (the patients who were playing the Boson $X$ video game, presented a lower rumination score and increased subjective cognition compared to the control group).

The effectiveness of post-stroke rehabilitation with the use of video games depends not only on the game type but also on the game mode. The competitive mode with a human rival is more promising for medicinal purposes than the single player mode because it is characterised by higher exercise intensity and a lower stress level. Scientists should be aware that it is worth conducting further experiments on rehabilitative potential of video games. It is so because results can be acquired with the use of various tests which assess the mobility of different body parts, so outcomes obtained with one test can differ from outcomes obtained by another, even if they pertain to the same video game. 
Perceiving video games as a therapeutic tool generates specific problems. Scientists pointed at the possibility that increased motivation reported for rehabilitative games may be an effect of novelty, and patients may eventually get bored of the exercises (Goršič, Novak, 2016, p. 4694). Therefore, it is worth studying the patients' motivation after a prolonged time period. An important fact concerns the propensity of virtual realities to cause nausea (Schmitt, Hoffman, Blough et al., 2011, p. 65), which can lead to ceasing the treatment. Moreover, clinical trials using video games are problematic or even impossible to randomise. This is so because both the experimental and the control groups would always notice if they are or are not playing a video game.

\section{References}

Aisen, M. L, Kerkovich, D., Mast, J., Mulroy, S., Wren, T. A. L., Kay, R.M., Rethlefsen, S.A. (2011). Cerebral palsy: Clinical care and neurological rehabilitation. Lancet Neurology, 10(9), 844-852.

Barcelona MAR Health Park Consortium (21 May 2015). El servicio de Medicina Física $y$ Rehabilitación del Hospital de la Esperanza aplica con éxito el Rehabilitation Gaming System (RGS) en un programa de rehabilitación post-ictus. Online: <https://www.parcdesalutmar.cat/es/noticies/view. php?ID=501>.

Bonita, R., Beaglehole, R. (1988). Recovery of motor function after stroke. Stroke, 19(12), 1497-1500.

Bonnechère, B., Jansen, B., Omelina, L., Jan, S. V.S. (2016). The use of commercial video games in rehabilitation. International Journal of Rehabilitation Research, 39(4), 277-290.

Cameirãol, M. S., Badia, S. B., Duarte, E., Verschure, P. F. M. J. (2008). Stroke rehabilitation using the rehabilitation gaming system (RGS): Initial results of a clinical study. In B. K. Wiederhold, L. Gamberini, S. Bouchard, G. Riva (eds.), Annual Review of CyberTherapy and Telemedicine (pp. 146-151). San Diego: Interactive Media Institute.

Catalán, J. M., Blanco, A., Díez, J.A., García, J.V., García-Aracil, N. (2019). Physiological reactions in single-player and competitive arm rehabilitation 
games. Annual International Conference of the IEEE Engineering in Medicine and Biology Society (pp. 433-436).

Committee on the Assessment of Ongoing Efforts in the Treatment of Posttraumatic Stress Disorder, Board on the Health of Select Populations, Institute of Medicine (2014). Treatment for Posttraumatic Stress Disorder in Military and Veteran Populations: Final Assessment. Washington: National Academies Press. Online: <https://www.ncbi.nlm.nih. gov/books/NBK224878>.

Fu, Z., Hong, H., Su, Z., Lou, B., Pan, C., Liu, H. (2019). Global prevalence of amblyopia and disease burden projections through 2040: A systematic review and meta-analysis. British Journal of Ophthalmology, 104(8), 1164-1170.

Gambacorta, C., Nahum, M., Vedamurthy, I., Bayliss, J., Jordan, J., Bavelier, D., Levi, D. M. (2018). An action video game for the treatment of amblyopia in children: A feasibility study. Vision Research, 148(1), 1-14.

Goršič, M., Novak, D. (2016). Design and pilot evaluation of competitive and cooperative exercise games for arm rehabilitation at home. Annual International Conference of the IEEE Engineering in Medicine and Biology Society (pp. 4690-4694).

Holmes, E. A., James, E. L., Kilford, E. J., Deeprose, C. (2010). Key steps in developing a cognitive vaccine against traumatic flashbacks: Visuospatial Tetris versus verbal Pub Quiz. PLoS One, 5(11), 1-9.

Hung, J. W., Chou, C. X., Hsieh, Y. W., Wu, W. C., Yu, M. Y., Chen, P. C. (2014). Randomized comparison trial of balance training by using exergaming and conventional weight-shift therapy in patients with chronic stroke. Archives of Physical Medicine and Rehabilitation, 95(9), 1629-1637. Jannink, M. J., Wilden, G. J., Navis, D. W., Visser, G., Gussinklo, J., Ijzerman, M. (2008). A low-cost video game applied for training of upper extremity function in children with cerebral palsy: a pilot study. Cyberpsychology Behavior, 11(1), 27-32.

Johnson, W., Onuma, O., Owolabi, M., Sachdev, S. (2016). Stroke: a global response is needed. Bulletin of the World Health Organization, 94(9).

King's College London for the Stroke Alliance for Europe (2015). The Burden of Stroke. Online: <https://strokeeurope.eu/executive-summary>. 
Kühn, S., Berna, F., Lüdtke, T., Gallinat, J., Moritz, S. (2018). Fighting depression: Action video game play may reduce rumination and increase subjective and objective cognition in depressed patients. Frontiers in Psychology, 9(129), 1-10.

Lee, H. Y., Kim, Y. L., Lee, S. M. (2015). Effects of virtual reality-based training and task-oriented training on balance performance in stroke patients. The Journal of Physical Therapy Science, 27 (6), 1883-1888.

Lissauer, T., Clayden, G. (2009). Zaburzenia rozwojowe i dziecko specjalnej troski. In T. Lissauer, G. Clayden, A. Milanowski (eds.), Pediatria (pp. 43-62, transl. Krawczyński M.). Wrocław: Elsevier Urban \& Partner. Manyande, A., Cyna, A. M., Yip, P., Chooi, C., Middleton, P. (2015). Nonpharmacological interventions for assisting the induction of anaesthesia in children (Review). The Cochrane Library, 7(1).

Mock, J. (2020). Pandemiczna trauma. Świat Nauki [polska edycja Scientific American], 15(6), 26-27.

Novak, D., Nagle, A., Keller, U., Riener, R. (2014). Increasing motivation in robot-aided arm rehabilitation with competitive and cooperative gameplay. Journal of NeuroEngineering and Rehabilitation, 11(64), 1-15.

Patel, S., Bhatnagar, A., Wear, C., Osiro, S., Gabriel, A., Kimball, D., John, A., Fields, P.J., Tubbs, R.S., Loukas, M. (2014). Are pediatric brain tumors on the rise in the USA? Significant incidence and survival findings from the SEER database analysis. Child's Nervous System, 30(1), 147-154. Pistoia, F., Sacco, S., Tiseo, C., Degan, D., Ornello, R., Carolei, A. (2016). The epidemiology of atrial fibrillation and stroke. Cardiology Clinics, $34(2), 255-268$.

Rabe-Jabłońska, J. (2011). Zaburzenia nerwicowe. In M. Jarema, J. RabeJabłońska (eds.),Psychiatria. Podręcznikdlastudentów medycyny (pp. 221-252). Warszawa: PZWL.

Saint-Martin, C., Apuzzo, S., Salman, A., Farmer, J. (2019). Hyperacute infarct on intraoperative diffusion imaging of pediatric brain tumor surgery. Canadian Journal of Neurological Sciences, 46(5), 550-558.

Sajan, J. E., John, J. A., Grace, P., Sabu, S. S., Tharion, G. (2016). Wii-based interactive video games as a supplement to conventional therapy for rehabilitation of children with cerebral palsy: A pilot, randomized controlled trial. Developmental Neurorehabilitation, 20(6), 361-367. 
Sandlund, M., Waterworth, E. L., Häger, C. (2011). Using motion interactive games to promote physical activity and enhance motor performance in children with cerebral palsy. Developmental Neurorehabilitation, 14(1), 15-21.

Sarris, J., O’Neil, A., Coulson, C. E., Schweitzer, I., Berk, M. (2014). Lifestyle medicine for depression. BMC Psychiatry, 14(107), 1-13.

Schmitt, Y. S., Hoffman, H. G., Blough, D. K., Patterson, R. D., Jensen, M. P., Soltani, M., Carrougher, G. J., Nakamura, D., Sharar, S. R. (2011). A randomized, controlled trial of immersive virtual reality analgesia, during physical therapy for pediatric burns. Burns, 37(1), 61-68.

Sin, H., Lee, G. (2013). Additional virtual reality training using Xbox Kinect in stroke survivors with hemiplegia. Stroke, 92(10), 871-880.

Walker, M. P., Brakefield, T., Hobson, J. A., Stickgold, R. (2003). Dissociable stages of human memory consolidation and reconsolidation. Nature, 425(9), 616-620.

World Health Organization (30 January 2020). Depression. Online: <https:// www.who.int/news-room/fact-sheets/detail/depression>.

World Health Organization (2020). Stroke, Cerebrovascular accident. Online: $<$ https://www.emro.who.int/health-topics/stroke-cerebrovascularaccident/index.html>.

\section{Ludography}

MacLarty, I., Kerney, J. (2004). Boson X [PC]. Ian MacLarty, USA.

Blue Planet Software (2007). Tetris Zone [PC]. Blue Planet Software, USA. The date of access to Internet sources used in the article: 12 December 2020 . 
Marcin M. Granat, M.A. - graduate of the Jagiellonian University, Medical College. Mpharm at the Children's Memorial Health Institute, author of articles about video games and science.

\section{Gry wideo jako narzędzie wspomagające leczenie}

Abstrakt: Celem pracy było określenie, które choroby charakteryzują się rosnącym czynnikiem zachorowalności, a następnie zbadanie, czy gry wideo mogą pomóc w ich leczeniu. Aby osiągnąć ten cel, przeszukano naukowe źródła literaturowe. Wyniki wykazały, że gry wideo są efektywnym narzędziem w rehabilitacji pacjentów po przebytym udarze. W porównaniu ze standardową rehabilitacją chorzy grający w gry wideo wykazywali poprawę motoryki kończyn górnych, lepszą równowagę statyczną i mniejszy lęk przed upadkiem. Podobnie istotna statystycznie poprawa, mierzona za pomocą testu Quality of Upper Extremity Skills Test, zaobserwowana została podczas rehabilitacji pediatrycznej grupy składającej się z chorych na dziecięce porażenie mózgowe. Gry wideo z powodzeniem wspierają też terapię innych dziecięcych chorób, poprawiając ostrość widzenia w przypadku dziecięcego niedowidzenia, jak również obniżając uczucie lęku podczas indukcji anestezji. Użyteczność gier wideo jest także zauważalna podczas leczenia chorób psychicznych. Dotyczy to pacjentów z zespołem stresu pourazowego, u których wykazano mniejszą częstotliwość powracania natrętnych myśli, jak również chorujących na depresję, u których zaobserwowano zmniejszenie się liczby ruminacji oraz zwiększenie subiektywnej oceny zdolności poznawczych. Wskazanie, które choroby cechują się rosnącą zachorowalnością i są jednocześnie podatne na leczenie za pośrednictwem gier wideo, dostarcza użytecznych informacji pracownikom służby zdrowia. Może też przyczynić się do poprawy terapii tych chorób.

Stowa kluczowe: gry wideo, rehabilitacja, pediatria, psychiatria 